坑道維持状況であるが, 今後衆知を集めて検討したい。 $7 \cdot 2$ 自走枠との組み合せ

昭和56年, 当鉣は現稼行区域から将来の稼行採掘区域にかけて, 石油探査技術として発達した海上物理探査を行ない, 翌57年に石 油掘さくリグを使用して海上ボーリングを実施した。その結果, 現稼行飛島区域の西方に南北約 $4.5 \mathrm{~km}$, 東西 $1.5 \mathrm{~km}$ に及ぶ平らな 構造 (SL-600〜800m) を発見し，炭層も現区域と大差ないこ とを確認した。

当然のことながら, 傾斜が緩く, 安定した炭層賦存状況となれ ば，自走枠を使用した重装備の完全機械化採炭が考えられる。

現在，当鉱が自走枠を使用できない理由は，前述のような飛島 区域の自然条件と，当鉱において真に成功した自走枠採炭の例が 少ないからである。

現稼行区域の厳しい自然条件が緩傾斜区域において, すべて解 消するとは考えられないが，少なくともフィールドの形や傾斜に 起因する制約は，大きく好転することが期待できるので，目下自 走枠採炭を検討中である。

今後の課題として,

(イ) 炭層をどの範囲（高層一段払か, 単層払か等) に分けて採 得するか。

(ロ) 曼適自走枠のタイプ，仕様は。
（〉）自走枠と組合せる採炭機は何を選ぶか。ドラムカッタは松 岩のため全く不向きか。

(二) 人員の配置は。

(杖払肩深坑道の維持と連接の方式は。

( 自走枠の投入，撤収の具体的方法は。

（ト）フィールド長は何米あれば，また能率はどの位向上すれば 採算が取れるか。

(千) 坑外の修理体制は，その他。 などである。

いずれにしても，西部区域へ全面移行するまでに，遺漏なきよ う万全を期して，検討を進める考えである。

\section{8. む す び}

以上，当鉱におけるホーベルの導入から，その変遷をたどり， 今後の検討課題も含めた概要をまとめてみたが，当鉱でレッべホ 一ベル導入時から，営々として引継いできたホーベル採炭技術が， 少しでも, 諸兄のご参考になれば誠に幸いである。

また今後の検討課題については，当鉱が三菱操業 102 年の歴史 の中で, 戦後の採掘は全て中傾斜層が対象で, 緩傾斜採掘の経験 が皆無に等しいことから, 諸先輩の暖かいご指導, ご教示を賜わ らんことを念じている。

\title{
The Hobel Mining at Takashima Colliery
}

\section{by Masahiro KAWASAKI}

The history of the hobel mining at Takashima Colliery is very long. It began with introducing the Löbbe hobel in December 1957, and has been followed by the Umbau hobel and Reisshaken hobel which are working as the main mining machines now.

Firstly the Löbbe hobel was introduced in order to increase the productivity in a thin coal seam (=Banto seam).

It proved fairly successful. duced.

Secondly in January 1961 the Umbau hobel which hobel and conveyor drive are done by different motors were intro-

And in 1962 the productivity was led to $7.6 \mathrm{t} / \mathrm{M} . \mathrm{S}$. in the Banto face.

Then, the heavy duty mechanization which combined the powered supports are the double drum shearer were proceeded.

But it had to be given up and it was taken the place by the single prop supports mining.

Because the barriers for the face mechanization are as follows.

1 the short working field 2 inclination 3 Matsuiwa (silicified hard rock in coal seam) 4 faults 5 the poor roof condition

To deal with these problems Takashima colliery looked for the new coal mining machine.

As a result the S-3 Reisshaken hobel was chosen because of its adaptability to the matsuiwa, the faults, the inclination, the single prop supports and the working height.

The production by it started in July 1979 and all faces are equipped with the hobel at present.

But there still remain a lot of problems concerning the face mechanization, especially such as the stable elimination and the combination with the powered supports.

The hobel mining has a long history, and today, the hobel occupies an important part in the coal winning machines in the the world, but the hobel mining is apt to be looked down, for the shearer mining occupies the speriority in number domestically.

This paper is nothing but discribing the hobel mining at a colliery, and yet it summarizes the introduction in the genesis of the hobel mining and its changes, present and future, so, it would be grateful, if it is useful to you.

\section{〔 2-4〕幌内炭鉱における薄層機械化採炭の方向について}

\section{進 藤 孝 ${ }^{1}$}

\section{1. はじめに}

蜆内炭鉱における，現在の稼行レベルはS.L.-1.000〜 -1.070 $\mathrm{m}($ 坑ロレベルS.L. $+55 \mathrm{~m}$ ) の深部に達しており, 走行方向には 約 $3 \mathrm{~km}$ に及ぶ採掘範囲は, 明瞭な断層によつて 3 区域に区分さ

1. 北炭蜆内炭鉱株式会社技術部副部長
れている。

稼行対象炭層は幾春別層中の 7 枚の炭層であるが, 第 1 表に示 すように, 稼行丈は $2 \mathrm{~m}$ 以上のものから $1 \mathrm{~m}$ 以下の薄層まで多岐 に亘つている。

中厚層切羽に対しては, 昭和 4 年以降, 自走枠を導入し, ダブ ルレンジングドラムカッタと組合せた, 重装備機械化採炭を実施 し, その間, 逐次新鋭枠種を増籍して, 切羽出炭の増強と能率の

$654<52>$ 
向上を図つて効果を挙げてきた。

一方, 稳行丈 $1.4 \mathrm{~m}$ 以下の炭層に対しては, 機械化のテンポが 遅れ, 在来方式の鉄柱, カッペにライスハーケン $\mathrm{G}$ 型ホーベル使 用の採炭を継続し，硬炭（FD 15～24）のため発破を必要とする 事情もあり, この方式による切羽能率の向上はほぼ限界に近づい ている。

この結果, 中厚層を優先採掘することになり, 採掘レベルの変 更時には, 薄層の一部は未採掘のまま取り残される事例が発生し ている。

今後, 当炭鉱にとつて長期に安定した出炭を確保し, 潹部化速 度を抑制していくための要件の一つは, 薄層の出炭力をあげて中 厚層切羽に近づけることである。
この課題の解決に向かつて, 昭和56年以来検討を重ねており, その第一段階として, 57 年度に薄層用ドラムカッタを遭入し切羽 稼働に入つている。

更に石炭技術研究所のご協力を得て, 57 年度中に薄層用自声支 保の現場テストに取組んでいる。

当炭鉱の自然条件に適合した, 薄層切羽における機䃆化の過在 と今後の方向について報告し, 諸賢のご批判を仰ぐ次第である。

$$
\text { 2. 茏切方法 }
$$

現在最も多く使用されている採炭機械は，ドラムカッタホー ベルであり, 前者は中厚層用として, 後者は薄層用として一般的 に広く採用されている。

策 1 表炭層柱状および分析表

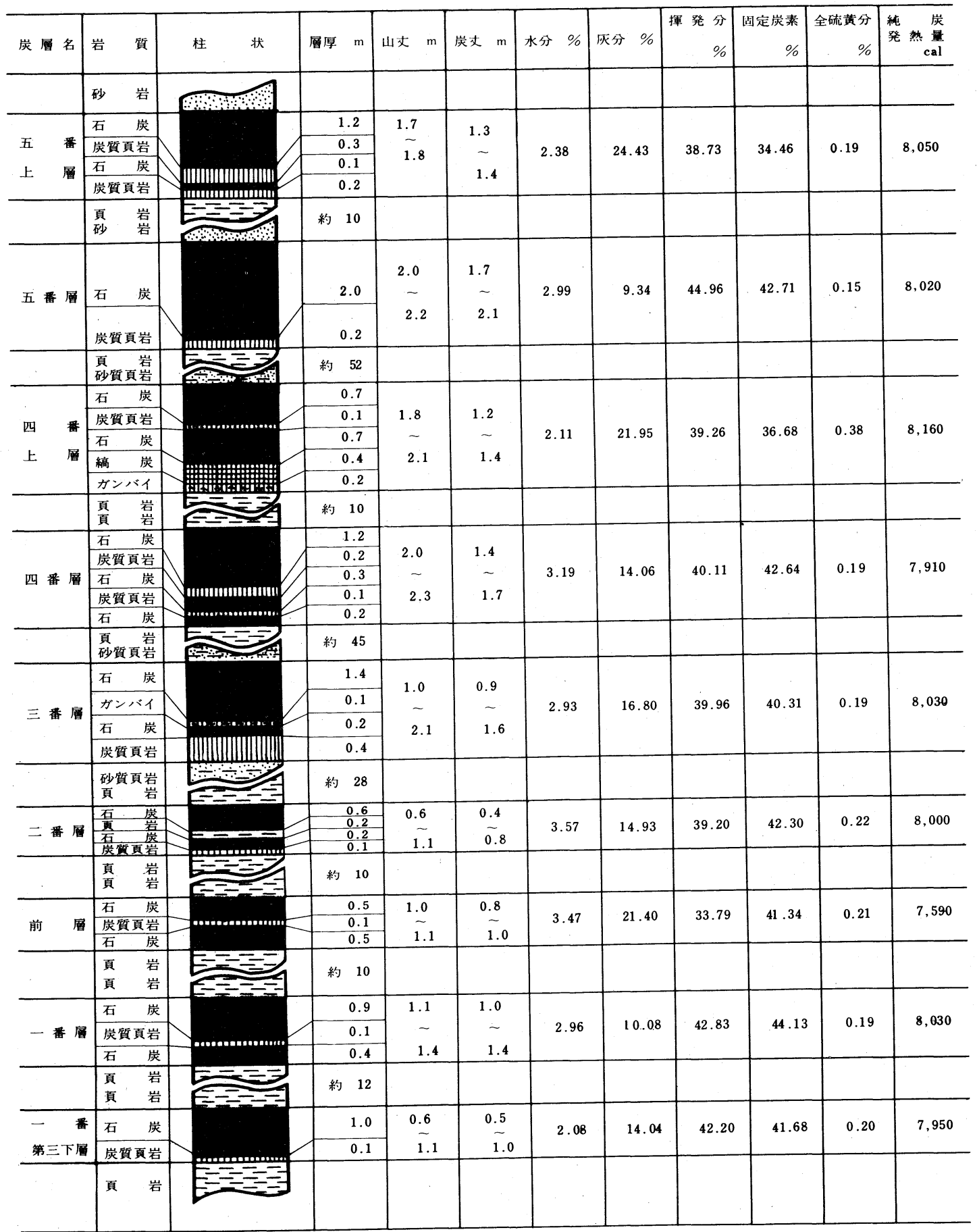



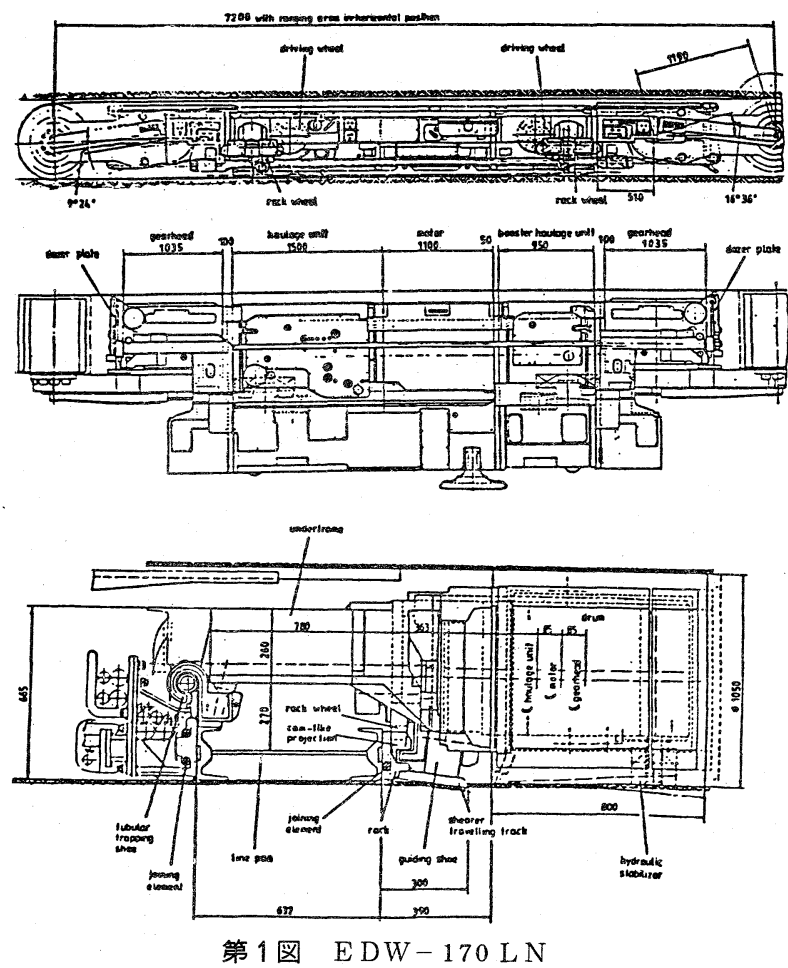

当炭鉱では薄層切羽に $\mathrm{G}$ 型ライスハーケンホーベルを使用して おり，硬炭時は，発破を併用した採掘となり，穿孔・発破時間が 採炭機械の手待ち時間となり能率孝下降させている。

硬炭に対しては, 最近では強力高速型のホーベルもあるが, 薄 層ドラムカッタの進歩がめざましく，当炭鉱では硬炭に対して既 に実績のあるドラムカッタの検討に入り，従来低姿勢のドラムカ ッタを使用したが中途半端であつたことから，完全な薄層ドラム カッタを検討することになつた。

方向としては, 薄層切羽にドラムカッタを導入して, その稼働 状況を検討し, 次に薄層自走支保の検討という二段ステップで薄 層に取組むことになつた。

ただし，薄層ドラムカッタは自走支保との組合せにより発達し てきた採炭機械なので, 鉄柱, カッぺとの組合せでは, 無理があ るが，その困難性を解決し実行に移すため種々の検討を加えた。

\section{$2 \cdot 1$ 現在使用中の機種との互換性があること}

使用中の機種 EDW- $340 \mathrm{~L}$ と互換性のある EDW- $170 \mathrm{LN}$ (第 1 図) と型式の選定をした。

結果的には電動機, カッタヘッド，ホーレジ部は全く同型で, 支持アーム部品に互換性のあることが判明した。

\section{$2 \cdot 2$ 硬炭切削が可能なこと}

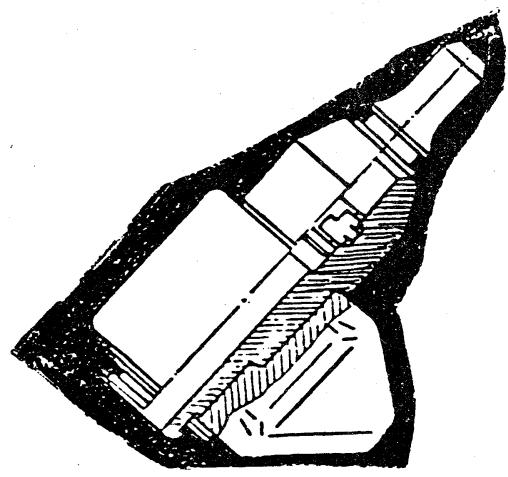

第 2 図 セルフシャープニングビット
硬炭に詨しては，十 分なホーレジ部の牽引 力があること，機体重 量があり切削時の震動 を吸収し機体の安定を はかること，その他と して, 硬炭用ビットと してセルフシャープニ ング型のビットを採用 してビットの変摩耗か らくる切削時の機体震 動を減少させることに した。第 2 四にセルフ

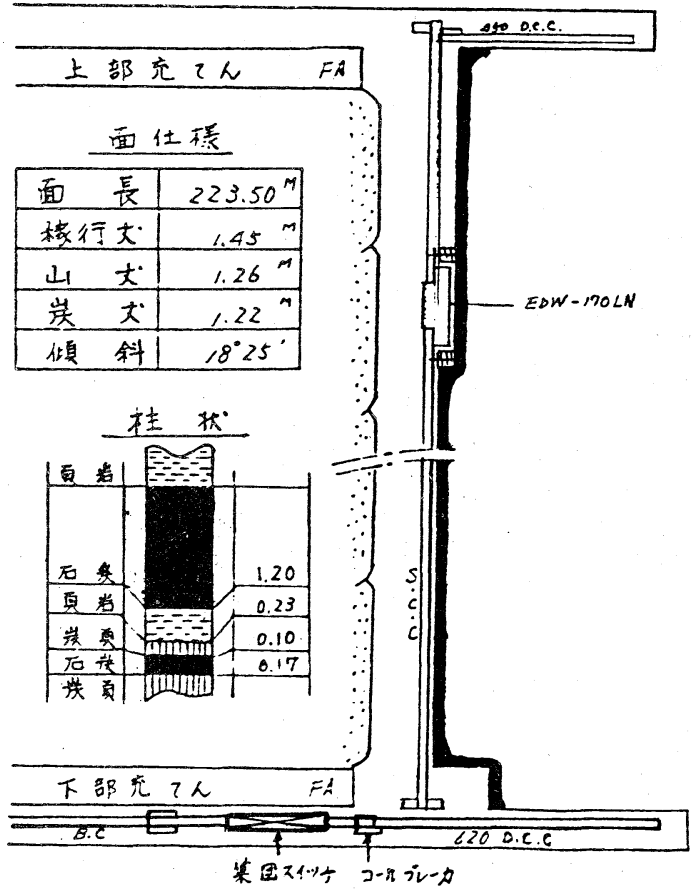

第 3 図 西部七片一層(奥)ロンク

シャープニングビットを示し, 構造は, ビット, スリーブ, ブロ ックの 3 部材でできている。

\section{$2 \cdot 3$ 下盤に対する追従性と移設力}

盤折れ，下盤起伏に対して追従性を良くするため, 従来ピニオ ン, ラック方式に取付かなかつた機体修正装置を取付可能として ラックの炭壁側に配置したこと，スタビライザ装置を取付けて機 体の安定運行が可能である。移設力は自走支保では問題とならぬ が, 鉄柱・カッペ切羽で使用する場合, シフタの強力な押力が必 要であり, シフタ用プロップの建付状況がむずかしく, ロータリ ーバルブでワンハンド操作可能としたが，これらに操作時間を要 している。

\section{$2 \cdot 4$ 切羽仕様}

第 3 図は, 現在薄層ドラムカッタを導入して稼働中の, 西部七 片一層(奥)ロングの切羽仕様である。

$2 \cdot 5$ ドラムカッタの稼行サイクル

薄層の鉄柱・カッぺ切羽で傾斜が $18^{\circ} 20^{\prime}$ の場合, 昇り切削時は 特に切削後の残炭により $5 \mathrm{t} / \mathrm{m}$ のシフタの力ではトラフを押しき れない。

ドラムカッタ採炭の稼行サイクルを定めるために，種々方法を 試みたが，鉄柱・カッぺ切羽では鉄柱の建付時 $0.7 \mathrm{~m}$ 移設しなけ れば鉄柱が建付かないし, 完全に移設立柱するために, 現在セン ターサンピング方式で稼働している。

薄層自走支保との組合せであれば，スネークサンピング方式が 可能となり，ドラムカッタ運行時間にロスがなくなる。

\section{$2 \cdot 6$ 薄層ドラムカッ夕主要仕様}

仕様の決定にあたつて, 最もワイドレンジであることを第 1 条 件として, 第 2 表のように決めた。

\section{$2 \cdot 7$ 薄層ドラムカッ夕実績}

第 3 表にその稼働実績を示すが，まだ稼働期間が短いこと， シフタ用プロップの移設, 建付等の操作不馴れがみうけられ, 当 初計画した能率にまだ達していない。

これも，鉄柱・カッぺ切羽との組合せという困難な条件と，切 羽傾斜が約 20 度あるためとおもわれる。

しかしながら硬炭に対しても，非常にバランスのとれた，音響 
第2表 主 要 仕 様

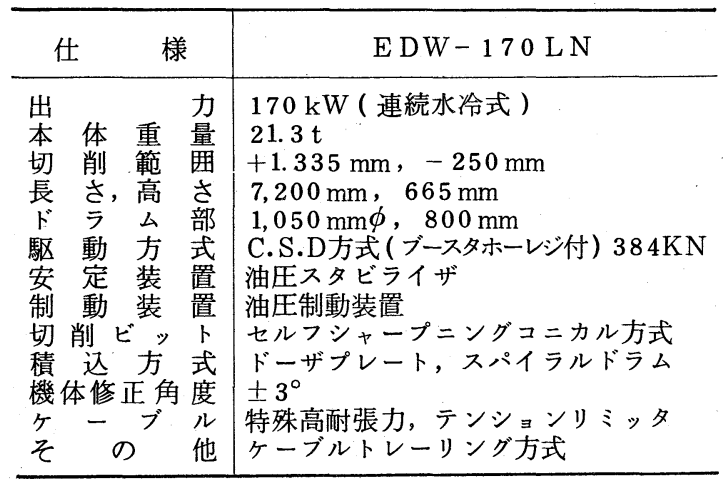

振動の少ない採炭機械である。

\section{3. 切羽運搬機}

最近の切羽運搬機は, 切削された石炭を運搬するという主目的 以外に, 採炭機械のガイドの役目, また自走支保の基準および移 設時の強勒な強度も具備していなければならない。

D.C.C.を使用時, 当炭鈗では硬炭硬岩のためドラムカッタで 淀み，それが原因で発生したチェンのトラブルが多かつたが，昭 和 47 年度から, S.C.C.を導入して上記のトラブルは解決した。

$3 \cdot 1$ トラフについて

自走支保とドラムカッタを組合せた場合, 切羽運搬機のトラフ の強度も一段と加わり, 薄層ドラムカッタと組合せた場合, 炭壁 側に走行ラックや走行ガイドがつき, かつ機体修正装置が取付く ために, トラフの接続は, その折れ角度が, 上に $2^{\circ}$, 下に $3^{\circ}$, 左 右に $2^{\circ}$ というきびしい条件がある。
(1) トラフ接続部強度
$850 \mathrm{KN}$ （3 D.C.方式）
(2) ラック付ウェッジ接続 $1,500 \mathrm{KN}$ (ドックボーン)
(3) チュブラガイド接続 $1,500 \mathrm{KN}$ (パンジョイント)

等の如く, 各部の強度があげられている。

第 4 図はラック付ウェッジで, ドラムカッタの走行ガイドにな つている。

第 5 図はパンジョイントを示すが, 図の如く隣接トラフにオー バラップされており，トラフ左右の折れ角度をかなり抑制してお り，トラフの型式も

$$
\mathrm{E}-72 \sim \mathrm{E}-72 \mathrm{~V} \text { ( 中板厚さ } 16 \sim 19 \mathrm{~mm} \text { ) }
$$

一般自走支保用
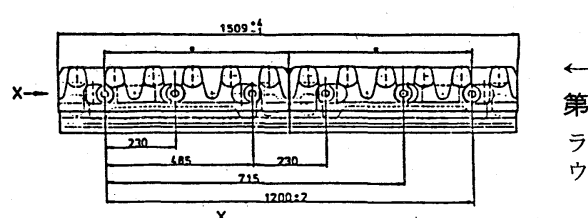

第 4 図

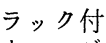

ウエッジ
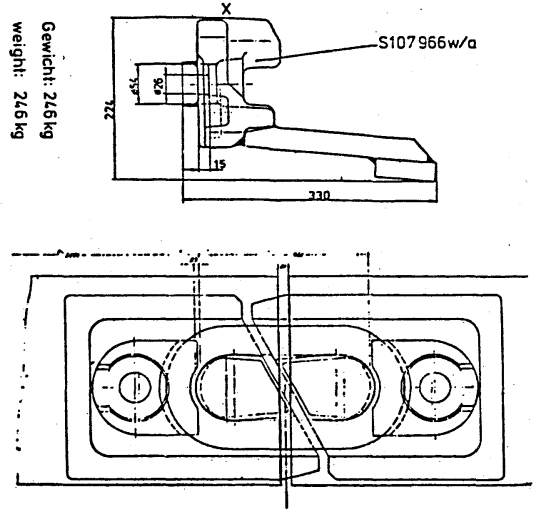

第5図 オーバラップパンジョイント
第3表 西部七片一層(奥)ロング実績表

\begin{tabular}{|c|c|c|c|c|c|c|c|c|c|c|}
\hline \multirow{2}{*}{\multicolumn{2}{|c|}{ 用到 }} & \multirow{2}{*}{\multicolumn{3}{|c|}{ 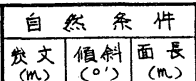 }} & \multicolumn{5}{|c|}{ 生萑状况 } & \multirow[b]{2}{*}{ 㒂考 } \\
\hline & & & & & 人具 & \begin{tabular}{|l|} 
原 \\
$(t / 6)$ \\
\end{tabular} & 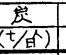 & 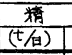 & 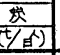 & \\
\hline \multirow{3}{*}{$\begin{array}{l}9 \\
\text { 月 }\end{array}$} & 平均 & 1.22 & 18.25 & 225 & 24 & 468 & 19.5 & 349 & $145^{5}$ & \multirow{2}{*}{ 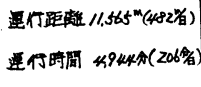 } \\
\hline & 最大 & & & & 26 & 665 & 25.5 & 496 & $19 . !$ & \\
\hline & 咶 & & & & 588 & $\begin{array}{r}5 / 2 / 8 \\
112 / 8\end{array}$ & 19.08 & 8,371 & 14.24 & 步留 $746 \%$ \\
\hline \multirow{3}{*}{$\begin{array}{l}10 \\
\text { 月 } \\
(z b)\end{array}$} & 平均 & 1.22 & $18^{25}$ & 223.5 & 40 & 693 & $27^{3}$ & $5 / 7$ & 今.0 & \multirow{2}{*}{ 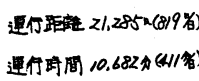 } \\
\hline & 最大 & & & & 48 & 975 & 20.5 & 728. & 5.2 & \\
\hline & 部 & & & & 1,028 & $\begin{array}{r}\text { 葋 } \\
88.017\end{array}$ & $17^{53}$ & $\begin{array}{r}t / 6 \\
3,451\end{array}$ & 13.08 & 步 留 $74.7 \%$ \\
\hline \multicolumn{2}{|c|}{$\begin{array}{l}9 \sim 10 \text { 月 } \\
\text { 25月 } \\
\text { 合 部 }\end{array}$} & \multicolumn{3}{|c|}{ 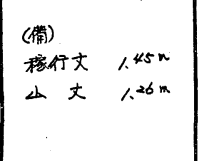 } & \multicolumn{2}{|c|}{$1,618|29,235|$} & 18. & $z 1.82 z$ & $心$ & 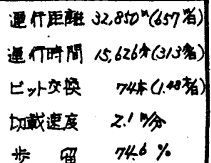 \\
\hline
\end{tabular}

$\mathrm{E}-74 \sim \mathrm{E}-74 \mathrm{~V}$ (中板厚さ $19 \sim 22 \mathrm{~m}$ )

シールド自走支保用

となり，強度，重量の増加と寿命も長く経済的になつた。

切羽運搬機としては，その自然条件に見合つた，かつ切羽条件 に適合したものを選択してゆく必要があり, 現在運搬能力の増加 のため, 運搬機のチェン速度を, より高速化する傾向にあるが, 忘れてならないことは, チェン速度に倍増してトラフ, チェンの 摩耗と電力消費量が増加することである。

\section{4. 自走支 保}

薄層という特殊な条件下の自走支保は, その投資効果が経済的 に引合うかどうか。

現在では中厚層切羽に匹敵できて, 経済性も十分あると, 薄層 切羽も近年見直されてきているが, 当炭鉱としても, 能率の高い 薄層機械化採炭の, 第 2 段階の検討事項としての自走支保が, こ の度, 石炭技術研究所のご協力を得て, 中傾斜薄層自走支保の自 動化と題して，57年度中に現場テストに取組んでいる。

薄層自走支保 (第 6 図) の設計概念として, 姿勢も $0.8 \sim 1.4 \mathrm{~m}$ の炭層にのみ適合するように限定し, 薄層切羽という歩行性の畺 い環境の中で自動化プランを折込み, エレクトロ, ハイドロシス テムのバッチコントロールを採用し, 肩隣接枠での単独操作も可 能とした。

$4 \cdot 1$ 自走支保の設計概念

(1) 枠姿 勢 $\min 0.65 \mathrm{~m} \max 1.5 \mathrm{~m}$ 組枠で坑内運搬可能

（2）架台 分割型間洩れ硑の排出用

(3) 主カッペ 一枚カッペ カッペ幅 $\min 1,350 \mathrm{~mm}$

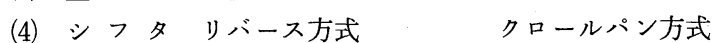

（5）炭層傾斜 $15 \sim 25^{\circ}\left(\max 35^{\circ}\right)$ 基準枠でズレ, 倒れ, 修正

(6) その他 ワンウェブバック方式

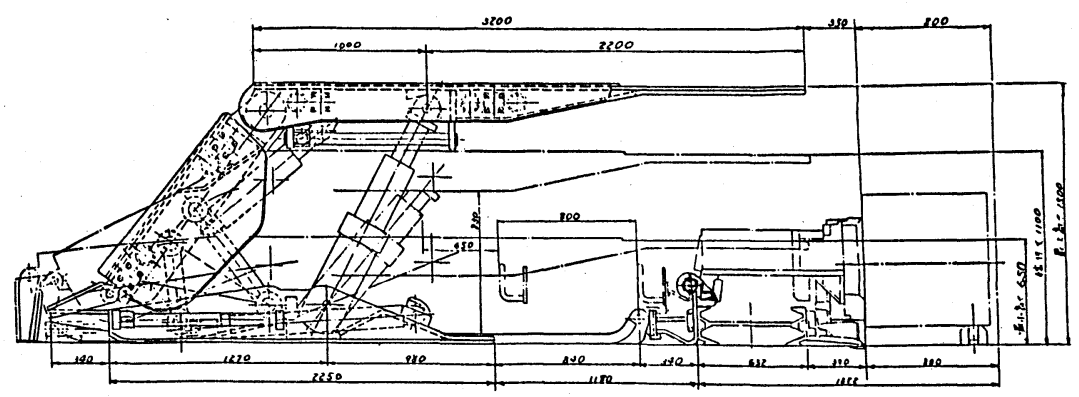

第6 図 薄層自走支保

日本鉱業会誌/991146（'83-8）657<55> 


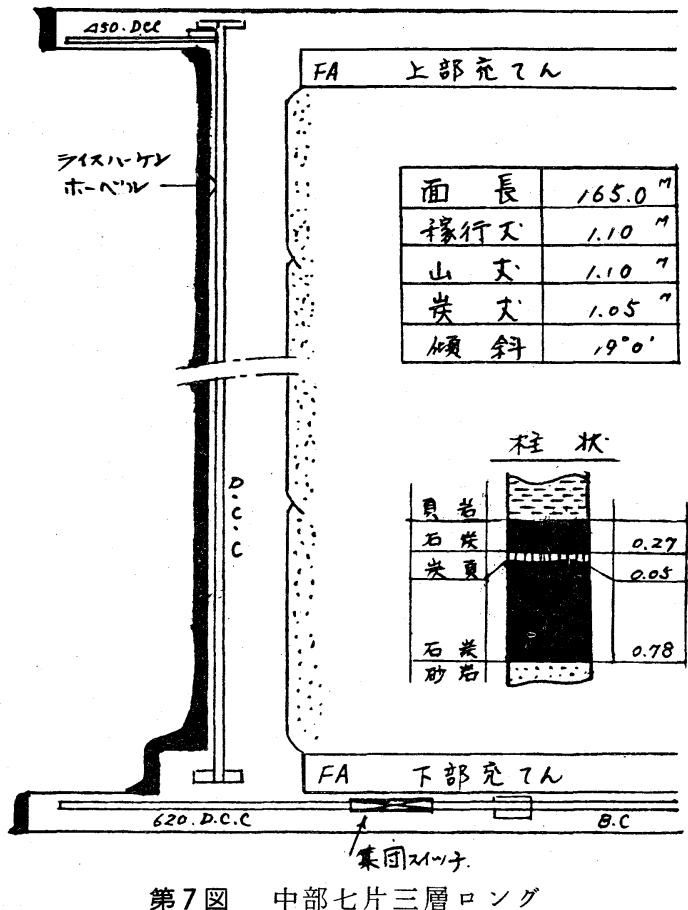

張出カッぺは左右に動かせること，通気抵抗を小さく，歩行間 を広くとる，蛍光灯はカッペ埋込型とする。

$4 \cdot 2$ バッチコントロール方式

（1）基準枠は組枠として，単独手動操作のみとする。

(2) バッチコントロールの範囲は枠の抜柱, 移設, 建付, ジョ イントジャッキ制御の 4 項目として, 試験は 1 バッチを 4 枠とし て最上部の枠でバッチ内制御をする。

（3）異状時は，隣接肩枠で単独手動操作ができること。

（4）枠間配管は多孔式マルチホース（14本組込）を採用して最 小限の配管とする。

\section{$4 \cdot 357$ 年度試験切羽概要}

57 年度の試験切羽は, 中部七片三層ロングとするが，58年度以 降は E DW-170 LN との組合せで行なう予定である。

同切羽は, 57 年 3 月に装備が完了した鉄柱，カッペとライス八 ーケンホーベルを組合せた切羽であつて, 概要は第 7 図に示す通 りで, 現在予備切羽となつている。

\section{$4 \cdot 4$ 薄層自走支保の主要仕様（第 4 表） \\ $4 \cdot 5$ 今後の検討課題}
（1） 1 バッチの枠数を何枠とするか
(2) コンベヤ押しは何バッチとするか
（3）傾斜対策としての基準枠について
(4) 電気, 油圧式制御の範囲
（5）使用時における操作性
(6) その他

現在, 基準枠 2 組, 普通枠 4 組の 6 枠が,中部七片三層アロング に装備されて試験中であり，当炭鉱の自然条件に適合するか，ま た薄層自走支保の操作性等についての試験結果は間もなくでるも のとおもう。
第 4 表 薄層自走支保主要仕様

\begin{tabular}{|c|c|}
\hline 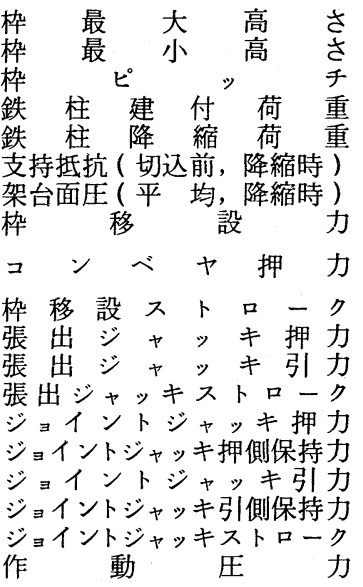 & $\begin{array}{l}1,500 \mathrm{~mm} \\
650 \mathrm{~mm} \\
1,500 \mathrm{~mm} \\
94 \mathrm{t} \times 2 \text { 本 } \\
110 \mathrm{t} \times 2 \text { 本 } \\
\max 35 \mathrm{t} / \mathrm{m}^{2} \\
10 \mathrm{~kg} / \mathrm{cm}^{2} \\
31 \mathrm{t} \\
16 \mathrm{t}\left(\mathrm{P}=300 \mathrm{~kg} / \mathrm{cm}^{2}\right) \\
8 \mathrm{t}\left(\mathrm{P}=150 \mathrm{~kg} / \mathrm{cm}^{2}\right) \\
800 \mathrm{~mm} \\
7.4 \mathrm{t}(\text { 保持力 } 8.1 \mathrm{t}) \\
3.6 \mathrm{t} \\
265 \mathrm{~mm} \\
42.9 \mathrm{t} \\
47.2 \mathrm{t} \\
27.9 \mathrm{t} \\
30.6 \mathrm{t} \\
266 \mathrm{~mm} \\
300 \mathrm{~kg} / \mathrm{cm}^{2}\end{array}$ \\
\hline
\end{tabular}

\section{5. おわりに}

以上, 当炭鉱における薄層機械化採炭の経過と方向について述 べてきたが，薄層専用のドラムカッタとしては，東洋ゾーンで始 めての採炭機械であり，その走行部の組立てには，予定以上の時 間を要したが，硬炭の切削に対しても，非常にバランスのとれた 音響, 機体振動の少ない採炭機械であるが, 故障時の修理には, 機体が炭壁側にあるので時間を要すことになるだろう。

ただし, 自走支保と組合せた場合, その能力を十分に発揮する と期待している。

切羽運搬機も，S.C.C.を導入して既に 10 年以上の実績があり， 炭層の厚薄に関係なく, 採炭機械や, 自走支保との適合性も良好 と判断している。

自走支保については, 石炭技術研究所のご協力を得て, 現在, 予定通り現場テスト中である。

今回は自走支保とドラムカッタが，それぞれ異なる切羽に設置 されたが,これらの実績が, 当炭鉱の薄層機械化採炭の空口を開 くことになる。

自走支保のバッチコントロールは，近年盛んになつているが， 実際の切羽では炭層に褶曲があり, 特に中傾斜切羽でのバッチュ ントロールは，傾斜対策と種々の修正動作を折り込む必要もある と考光られる。

したがつてバッチュントロールは歩行性の悪い薄層切羽にこそ 欠かせない技術であり，将来的にはバッチコントロールは個々の自 走支保が独立したロボット化して，制御に対して反応しなければ ならない。

ドラムカッタについても, 薄層といら走行性の悪い環境で, オ ペレータが所定の操作をしながら切羽進行を維持することは, 負 担も非常に多く, 作業能率も悪く, その負担を取除くために, リ モートコントロール，またはラジオコントロールにしてゆくのが 効果的と予想される。

現在, 中厚層切羽は既に能率面や，その経済性からみて，安定 したといえるが，薄層機械化採炭は，いまスタートしたばかりで あるが, 中厚層切羽に匹敵する切羽として, 安全性の確保と, 生 産性の向上をはかつて, 鋭意努力してゆきたいと考えている。

\section{Direction of the Mechanization of}

\section{Coal-Getting in Thin Seams at Hokutan Horonai Colliery}


We invested heavily in the medium seams to raise the productivity by a high degree of mechanization.

As the next step, to realize an economic coal-production in thin seams became our important and pressing problem. Therefore, we have been studying and advancing the mechanization of coal-production in thin seams since the Fiscal Year 1981.

We selected Drum Shearer EDW-170-LN as we judged it could cut our hard coal having FD15-24 in hardness without any anxiety. It has the favourable interchangeability with other machines in us in respect of spare parts. And, also, we chose strong Face Conveyor having bottom plates of $22 \mathrm{~mm}$ thickness and the strongest connection in order to guide the Drum Shearer smoothly, to keep the supports' positions right and to get long life.

Now, we are studying about a support most suitable for our conditions. Therefore, we have a big expection for the trial Shield Support, which CMRC will test at Horonai before long. The concept of principal design adopted into it is as follows:

1) To fit for seams having $0.8-1.5 \mathrm{~m}$ in thickness.

2) To employ Crawl-pan System to obtain a good path.

3) To employ Batch-control System as the control system.

4) To employ multi-tube hose between two supports.

We think that it is necessary for us to advance the elimination of labour by further automating.

We intend to make an effort to raise the productivity and to attain the fully safety for coal-getting in this seams.

\section{〔 2-5〕 南大夕張炭鉱における機械化の足取りと今後の方針}

\section{1. 緒言}

当鉱の稼行炭層は, 上層, 本層, 下層の 3 枚であり, これらは 他に類を見ないほぞの複雑な地質構造の中にある。

したがつて, 開鉱当初よりエヤブラスタによる無爆薬採炭を基 本とし，好条件を期待できる区域以外㤬全て単柱支保を採択して きた。採掘の機械化を阻害する要因としては，次のことが上げら れる。

(1) 炭層は中傾斜 $\left(15^{\circ} \sim 45^{\circ}\right)$ に加光褚曲, 断層, 下盤隆起等 が頻発する上，天盤が脆弱である。

(2) 中傾斜に加えアンジェレーションが激しいため機長の長く なる採炭機抢よびリジットにセットされるコンベヤ，自走枠等は 起伏变化への追随が困難である。

(3) 炭層が非常に軟弱 $(F D \doteqdot 52)$ なため炭壁が直立に存在す ることがなく，カッペ先が常に $1 \mathrm{~m}$ 前後空き天となり，軟弱天盤 保護のため施す炭壁立柱が機珹走行時の障害々なる。

(4) 盤压による坑道の狭小化が著しく, 機械搬出入のための坑 道整備に莫大な人員を要し, 重装備機械 化の障害となる。

（5）沿層片盤坑道は全て水平に設定し ていることにより炭層走向の変化に応じ て払長は肩深にそれぞれ伸縮するため, この部分は予め最縮時を想定して単柱を 使用せざるを得ない。

この環境条件の中で現在は 4 払体制, 年産 100 万 $\mathrm{t}$ の規模で操業中であり,そ の採炭方式比率はほぼ機械化払 2 払, 一 般払 2 払となつている。

開鉱以来の出炭実績拉よびその採炭方 式別比率を第 1 図に示す。

2. 機械化（生廉性向上)への足取り

\section{今 野 雅 博 $^{1}$}

前記劣徳なる採掘状況の他, ガス湧出量大, 自然発火性向大, 等の保安的制約も多い中で, 機械化に対しては圧気動DC から始 まり種々取組んできたが，採炭方式別払数の推移および切羽能率 の推移を第 2 図に示す。

$2 \cdot 1$ 採炭方式別能率向上策

(1) 一般払 (単柱, ピック払)

開鈸当初より内装型油压鉄柱 $2 \mathrm{P}-80$ 型 $(2.4 \mathrm{~m})$ を使用しエヤ ブラスタ，ピックの併用採炭を実施してきたが，資源を残さず採 掘すること並びに支保労働力の軽減を図ることから，軽合金製長 尺鉄柱を導入して稼行丈の増大により切羽能率の向上を図ってき た。その経過は

\begin{tabular}{|c|c|c|c|}
\hline 昭 52 & 内装型油圧鉄柱 & $\begin{array}{l}\text { 2ALP - } 80 \text { 型 } \\
\text { (下柱のみアルミ) }\end{array}$ & $(2.6 \mathrm{~m})$ \\
\hline & 外装型水圧鉄柱 & $\begin{array}{l}30 \mathrm{AL}-2.8 \text { 型 } \\
\text { (全柱ーアルミ) }\end{array}$ & $(2.8 \mathrm{~m})$ \\
\hline & 外装型水圧鉄柱 & $\begin{array}{r}30 \mathrm{AL}-3.0 \text { 型 } \\
\text { (全柱ーアルミ) }\end{array}$ & $(3.0 \mathrm{~m})$ \\
\hline
\end{tabular}
で現在は全払とも主力は $3.0 \mathrm{~m}$ 鉄柱である。 $\pi$ 例

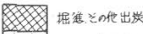
ビッフ払出岗

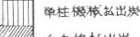

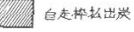

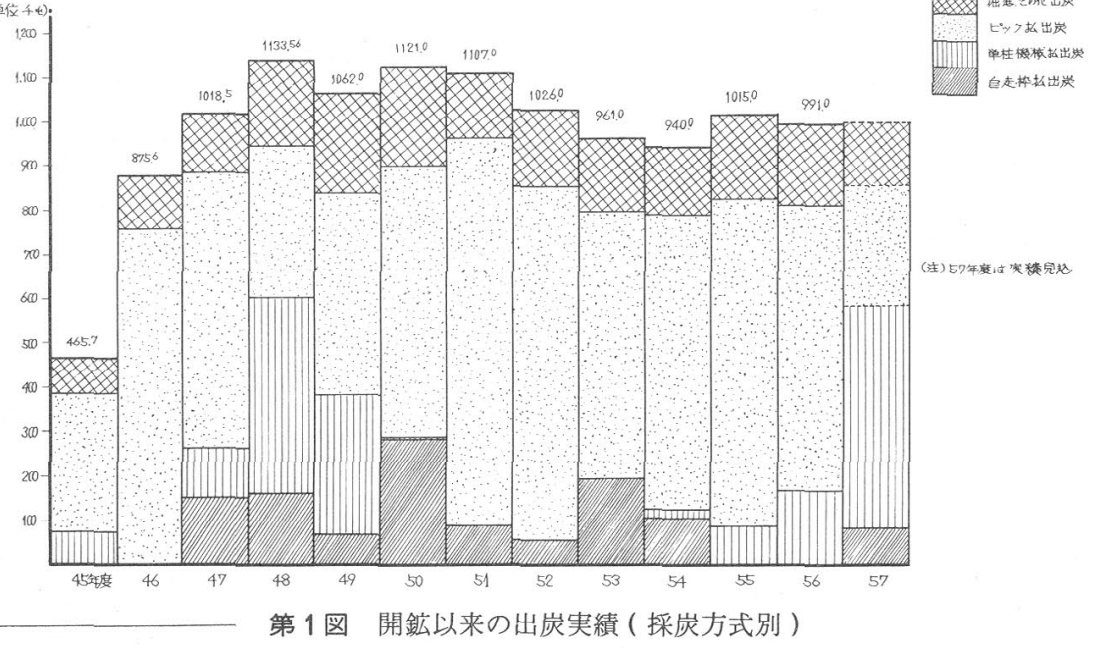

1. 三菱石炭鉱業株式会社南大夕張吰業所矿務課長 